\title{
Use of anatomical models in the teaching of veterinary anatomy as an animal welfare strategy
}

\section{Uso de modelos anatómicos en la enseñanza de la anatomía veterinaria como estrategia de bienestar animal}

\author{
ALCÁZAR-CHÁVEZ, Itzcoatl ${ }^{1}$, OLMEDO-PÉREZ, Gerardo ${ }^{1}$, ESTRADA-DÁVILA, María Graciela ${ }^{2}$ \\ and TABAREZ-ROJAS, Abigail ${ }^{1 *}$
}

${ }^{1}$ Facultad de Ciencias Biológicas y Agropecuarias, Universidad Veracruzana. Tuxpan, México. Facultad de Ciencias Biológicas y Agropecuarias de la Universidad Veracruzana. Carretera Tuxpan-Tampico Km. 7.5, Colonia Universitaria, Tuxpan, Veracruz, México, CP 92895

${ }^{2}$ Facultad de Ciencias de la Salud. Universidad de las Américas. Quito. Ecuador. Universidad de las Américas. Vía a Nayón S/N. CP 170125

ID $1^{\text {st }}$ Author: Itzcoatl, Alcázar-Chávez / ORC ID: 0000-0003-2405-8613

ID $1^{\text {st }}$ Co-author: Gerardo, Olmedo-Pérez / ORC ID: 0000-0002-1232-8236

ID $2^{\text {nd }}$ Co-uthor: María Graciela, Estrada-Dávila / ORC ID: 0000-0002-2703-7888

ID $3^{\text {rd }}$ Co-author: Abigail, Tabarez-Rojas / ORC ID: 0000-0002-8766-6993, CVU CONACYT ID: 176667

DOI: $10.35429 /$ JOTE.2021.15.5.15.29

Received July 10, 2021; Accepted December 30, 2021

\begin{abstract}
Anatomy is the science that studies the macroscopic composition of animal body and is a fundamental pilar within the discipline of veterinary medicine, for its study over the years animals and their corpes have been used, but today several changes: social, cultural and environmental, as well as the human- animal connection, are forcing institution to implement bioethical alternatives to the use of these. The purpose of this compilation is to provide an up-to date overview of the use of anatomical models in the teaching of veterinary anatomy as an animal welfare strategy, based on the 3R's principles proposed by the OIE, in order to make know the different alternatives that currently exist to the use of cadavers and vivisection, as well as the advances in technological innovation in the teaching of veterinary anatomy and its applications within the specialty
\end{abstract}

Anatomical models, Animal welfare, Bioethical alternatives

\begin{abstract}
Resumen
La anatomía es la ciencia que estudia la composición macroscópica del cuerpo animal, y es pilar fundamental dentro de la disciplina de la medicina veterinaria. Para su estudio, a través de los años, se han utilizado animales y sus cadáveres, pero en la actualidad diversos cambios sociales, culturales y ambientales, así como el vínculo humano-animal, están obligando a las instituciones a implementar alternativas bioéticas al uso de estos. El objetivo de esta recopilación es proporcionar un panorama general y actualizado sobre el uso de los modelos anatómicos dentro de la enseñanza de la anatomía veterinaria como estrategia de bienestar animal, en base a los principios de las 3R's propuestos por la OIE, con la finalidad de dar a conocer las diferentes alternativas que existen en la actualidad al uso de cadáveres y la vivisección (disección practicada en un animal vivo, con el propósito de hacer estudios o investigaciones científicas), así como los avances en innovación tecnológica en la enseñanza de la anatomía veterinaria y sus aplicaciones dentro de la especialidad.
\end{abstract}

Modelos anatómicos, Bienestar animal, Alternativas bioéticas

Citation: ALCÁZAR-CHÁVEZ, Itzcoatl, OLMEDO-PÉREZ, Gerardo, ESTRADA-DÁVILA, María Graciela and TABAREZ-ROJAS, Abigail. Use of anatomical models in the teaching of veterinary anatomy as an animal welfare strategy. Journal of Technical Education. 2021, 5-15: 15-29

\footnotetext{
* Correspondence to Author (e-mail: atabarez@uv.mx)

$\uparrow$ Researcher contributing first author.
} 


\section{Introduction}

Anatomy is the science that studies the macroscopic composition of the animal body, and is a fundamental part of the discipline of veterinary medicine. For its study it is divided into descriptive anatomy and dissections and topographic anatomy. For many years this science has used animals and their corpses for its study and understanding (Dyce et al., 2012), but today these practices are being questioned from various aspects such as: animal rights, animal welfare, operating costs, feasibility, management and reproducibility of the exercises (Ortíz, 2015). Currently there are more and more alternatives for the practice and teaching of veterinary anatomy such as artificial models, whether physical or virtual (Molina et al., 2012). According to Martínez and Romero (2010), it is important to find tools that facilitate learning, but also their evaluation, therefore, educational measurement and evaluation constitute key processes linked to the teaching-learning process and represent fundamental tools for the decision making within an institution. Flores et al. (2017) mention a definition of didactic strategy as "procedures and resources used by the teacher to promote meaningful learning, intentionally facilitating a processing of new content in a more profound and conscious way".

In the process of organizing teaching, didactic strategies are useful tools that help the teacher to communicate the contents and make them more accessible to the student's understanding. A teaching strategy is not valuable in itself; Its value is in facilitating student learning and in generating more pleasant and conducive environments for university education (Flores et al., 2017) and it is under these statements that the viability of the use of anatomical models in the teaching of veterinary anatomy.

Therefore, this work is a compilation of information on the use of anatomical models in veterinary education, their historical background, the different types and variables that exist, the justifications for their use, the advantages and disadvantages that they present, as well as the future challenges within veterinary education.
This document is intended to be a support guide for teachers and students of the degree in veterinary medicine and zootechnics, on the use of models in the teaching of veterinary anatomy as an animal welfare strategy, so that with it they can learn about the different tools that currently exist and where the scientific and technological development in the veterinary field is going, with a future objective that they can visualize a little explored and diffused area of the profession of veterinary medicine that is the innovation and development of alternative technologies to use of animals in education, as well as serving as a background for future research in the field.

\section{Historical background of the use of animals in education}

According to Téllez (2012), vertebrate animals are fundamental in biomedical sciences, since they have been used as models to understand the causes, diagnosis and treatment of diseases that affect humanity and animals, as well as contributions to education superior and specializations, in the development, production and control of medicines, food and other supplies. The history of the use of animals in education is related to the beginning of the experimental use of animals as models of human anatomy, physiology and psychology, it is believed that the practice of dissection was introduced in education, especially medical, during the 12th and 20th centuries. XIII. Once the similarity between the human body and the animal was established, this practice became common..

\section{Historical background of the use of anatomical models in veterinary education}

From the end of the VXII century to the midXIX century, a multitude of anatomical models were created for educational purposes and different materials (waxes, paper mache, wood, plaster) that were of great importance for the transmission of scientific knowledge due to the impossibility of conserving corpses, especially in hot season (Hernández et al., 2018). In the veterinary discipline according to Trujillo (2016), it was from 1761 with the creation of the Ecole Vétérinaire de Lyon, France, when anatomical models began to be used within the collections in the museums of the higher schools. 


\section{Description of the anatomical models developed and used in the teaching of veterinary medicine}

Currently, as mentioned by Knight (2008), there are more and more alternatives for the practice and teaching of veterinary anatomy, among these alternatives are artificial anatomical models, computer models, electronic simulators or augmented reality. The different types of models and their variants are described below.

\subsection{D or two-dimensional anatomical models}

Within this category are the manuals (Fig. 1) atlases, coloring books, posters, photographs, digital presentations, drawings, diagrams and any two-dimensional representation that is used in the teaching and learning activities of veterinary anatomy ( Nieto et al., 2014). Chaix and Méniel (2005) mention that the determination manuals are based on the graphic representation of the various bones and that they sometimes include the indication of the constant characters (family, genus and species). They mention that for the approach to anthropozoology they are a good introduction, but they are not enough for the practical understanding of this science.

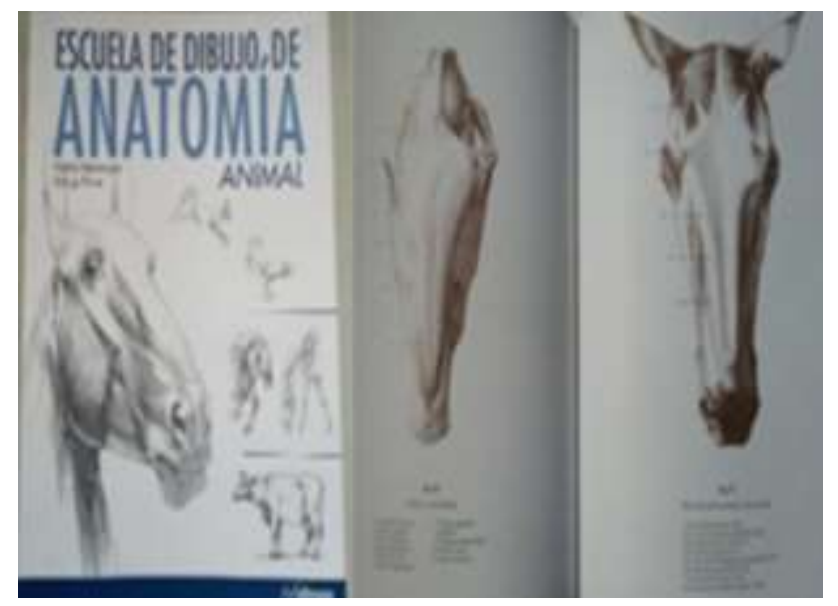

Figure $12 \mathrm{D}$ didactic anatomical model

Source: Szunyoghy \& Fehér, (2010)

\subsection{Audiovisual anatomical models}

According to Soler et al. (2016) are resources that are presented as a realistic alternative to dissecting animals, it is a support material that precedes surgical practice in simulators or work in these species.
They can be used by students and serves as entertainment before practicing with corpses. According to Bastida and Morales (2015), audiovisual resources are part of the didactic resources called multisensory. The use of videos (Fig. 2) in medical higher education has shown to have excellent pedagogical utility, in universities worldwide they have been used in the teaching of anatomy, surgical, exploratory techniques, or even communication skills (Villaescusa et al., 2014).

Tabares (2018) and Terrado et al. (2018), mention that new technologies such as WhatsApp, Facebook, Twitter, Instagram, are tools that facilitate the transfer of audiovisual information remotely, thus allowing access to information.

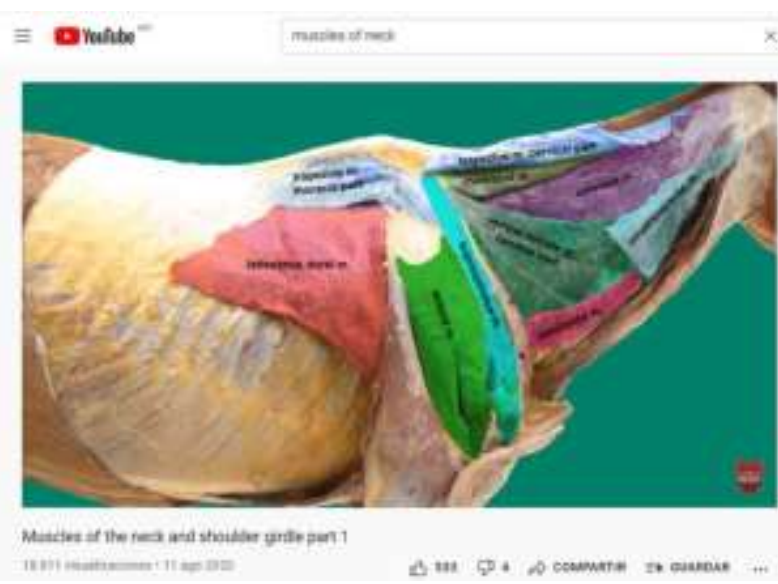

Figure 2 Audiovisual model (video)

Source: Veterinary anatomy. Muscles of the neck and shoulder girdle part 1. Available in: https://www.youtube.com/watch? $v=F k v 6 j k l 894 M \& t=256$

\subsection{Organic anatomical models}

Molina et al. (2019) mentions that there are several techniques for the conservation of corpses, in order to appreciate the anatomical characteristics of animals and understand their role in practical teaching, of the units of anatomy and veterinary embryology, they usually use materials such as bones (Fig. 3 ), fresh muscles and organs, or regularly fixed or preserved material (from slaughterhouses or corpses obtained after the humane slaughter of domestic animals), due to its short duration, which is approximately seven to ten days maximum, it is very expensive. For this, the products most frequently used for their quality and low cost are formaldehyde as a fixative and phenol as an antifungal. 
Both products are classified as highly toxic and are very volatile, therefore, according to the legislation, their use is restricted in relation to the environmental levels allowed for these substances, which results in strong economic investments in the installation of extraction systems. adequate so that the environmental levels of the substances are allowed.

Currently, according to Sánchez et al. (2012), Molina et al. (2019) and Frías (2019), there are other alternatives to those conventionally used for the preservation of anatomical pieces based on formaldehyde such as transparency, filled with silicone, paraffinization, the use of crystallized resins as well as the plastination technique (Fig. 4 ), which is based on the replacement of organic fluids (mainly tissue water and part of the fats) by silicones, polyester resins or epoxies, which allow the conservation of biological material eternally, and has the advantage of being stored without the need for essential conditions and with the advantage of being innocuous and devoid of toxicity for those who handle it. With this technique, anatomical pieces with higher quality, dry, odorless, non-toxic and with unlimited duration are obtained, which allows its use in teaching (López, 2019).

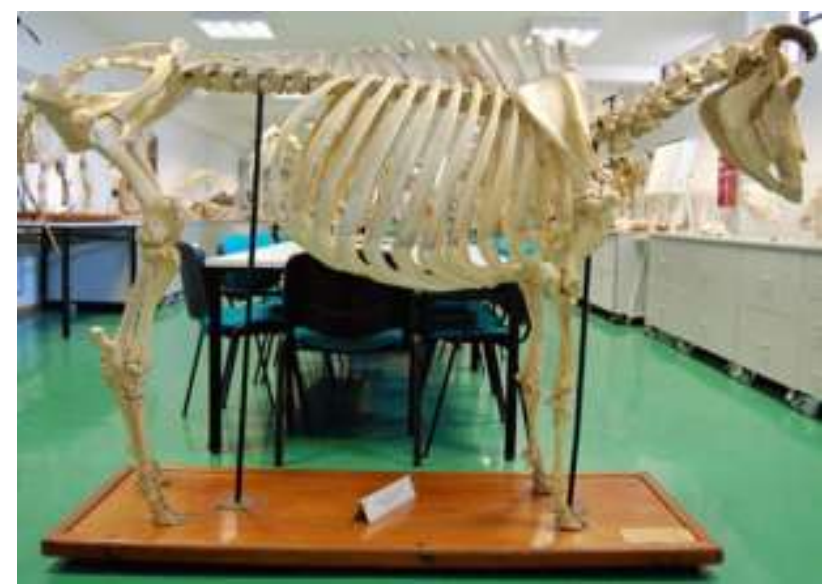

Figure 3 Bovine Skeleton Organic Anatomical Model Source: Murcia Anatomy Museum. Available in: https://www.um.es/web/museo-

veterinario/colecciones/esqueletos
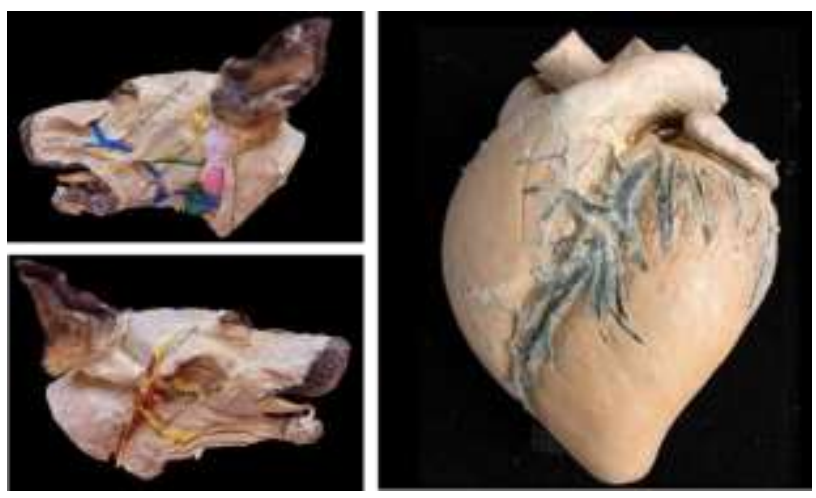

Figure 4 Plastinated organic anatomical models

Source: Murcia Anatomy Museum. Available in: https://www.um.es/web/museo-

veterinario/colecciones/piezas-plastinadas

\subsection{Organic anatomical models with interventions of synthetic materials}

Balastegui et al. (2018) describes them as follows: they consist of two components, one synthetic and one organic, these models are made on a chemically preserved organic base (Fig. 5) and a synthetic component (plasticine, clay, plaster, wax, fabric, paper, resin, etc.). These models allow direct interaction with the pieces and develop creativity and problem solving. The advantage of these models is that they will remain as part of the inventory of anatomical resources for later use (Fig. 6).

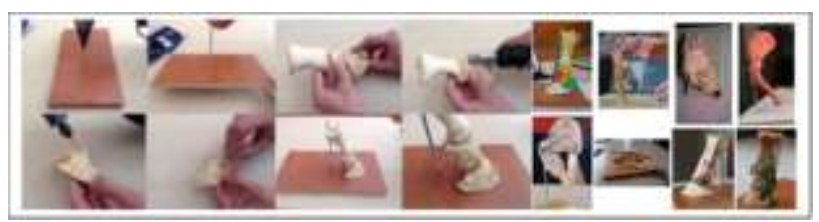

Figure 5 Anatomical models made by students Source: Balastegui et al. (2018)

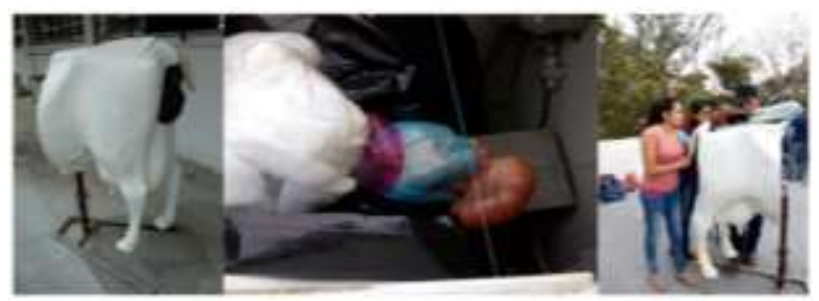

Figure 6 Mixed model (simulator of artificial insemination and reproductive system of bovine female) Source: Personal Photography

\subsection{Inanimate anatomical models}

According to Tamayo et al. (2019) and Lenis et al. (2019) artificial models are a representation of a part or a replica of the body, which present the anatomy in a more simple way, which facilitates its understanding.

ALCÁZAR-CHÁVEZ, Itzcoatl, OLMEDO-PÉREZ, Gerardo, ESTRADA-DÁVILA, María Graciela and TABAREZ-ROJAS Abigail. Use of anatomical models in the teaching of veterinary anatomy as an animal welfare strategy. Journal of Technical Education. 2021 
These exist in various presentations such as mannequins that are assembled by anatomical pieces or simply organs or fixed whole bodies, that is, they do not present a physical interaction beyond contemplation, the didactic utility of these models is based on the following aspects: it can be used outside the laboratory without exposure to substances with a health risk, they allow better visualization of some structures that are difficult to visualize in a real corpse, which improves the learning process. These can be industrially manufactured (Fig. 8) or elaborated in a traditional or artistic way by students (Fig. 7) or teachers, through the use of 3D printing (Calavante et al., 2020).

According to Payró (2015), Lenis et al. (2019), Balastegui et al. (2018), the advantages that can be attributed are that they allow various interactions with other types of models such as virtual ones, preserved organic anatomical models and other didactic techniques such as body painting and body projection. Disadvantages are poor access to these resources due to cost or availability by manufacturer location.

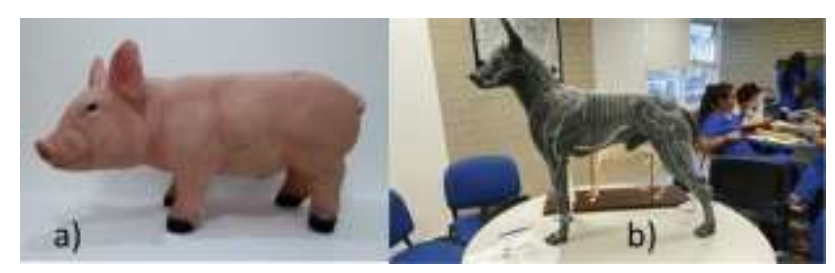

Figure 7 Inanimate artificial anatomical models: a) artisan b) industrial

Source: Personal Photography

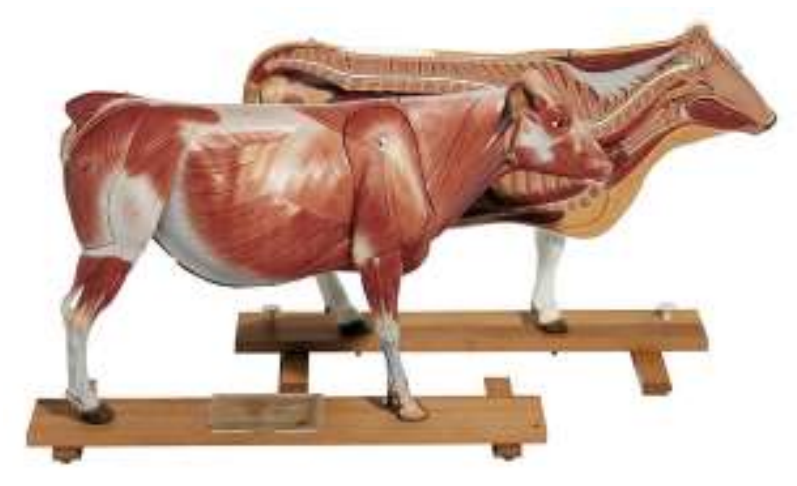

Figure 8 Industrial bovine anatomical model, lateral view

Source: $\quad$ https://www.somso.deles/zoologie/animvertebrados/vacal

\subsection{Body painting}

According to Sattin et al. (2018) the body painting technique was introduced by Op den Akke in 2002, as a method of teaching human anatomy. This form of body art is enjoying increasing popularity in veterinary medicine, particularly for the study of equine anatomy (Fig. 9), as it provides a faithful representation of various anatomical structures through painting on the skin. Body painting is an innovative and promising method of teaching anatomy that, if combined with classical methods of teaching anatomy, has great applicability in veterinary education (Senos et al., 2015; Sattin et al., 2018). This auxiliary method allows students to associate anatomical structures with their respective locations and is believed to complement traditional anatomy teaching.

The use of new techniques that are based on live models is still rare in the teaching of veterinary anatomy and raises animal welfare concerns, however, living anatomy as Sattin et al calls it. (2018) to the technique of body painting and palpation, is increasingly gaining recognition as an alternative to the use of corpses. The body painting technique also has drawbacks, such as the need for a highly capable artist and the level of physical stress to which the horse is subjected during the long procedure, if it is not treated properly. Also, palpation should be avoided, as direct contact can damage the artwork over time, just like the horse lying in the stable. For this reason, friendly and accessible techniques have been developed based on the use of a type of disguise or shirt (Fig. 10), in which the skeleton of the equine is painted, thus guaranteeing the use of the body painting technique in equines that suffer a lot of stress from driving (Sattin $e t$ al., 2018).

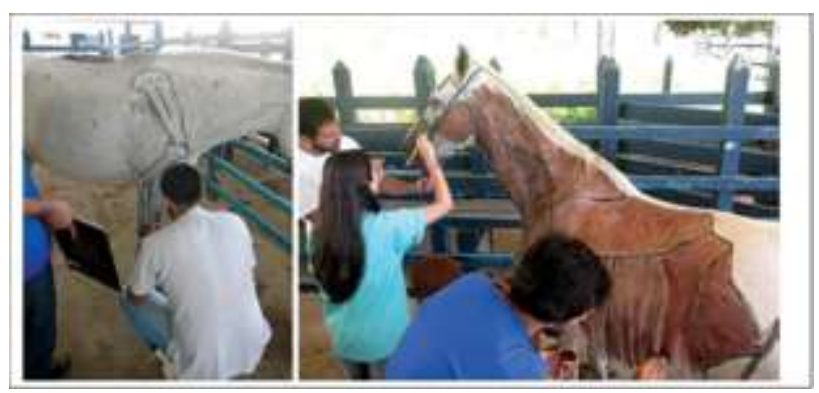

Figure 9 Drawing of bones and muscles on the skin of an equine

Source: Senos et al. (2015) 


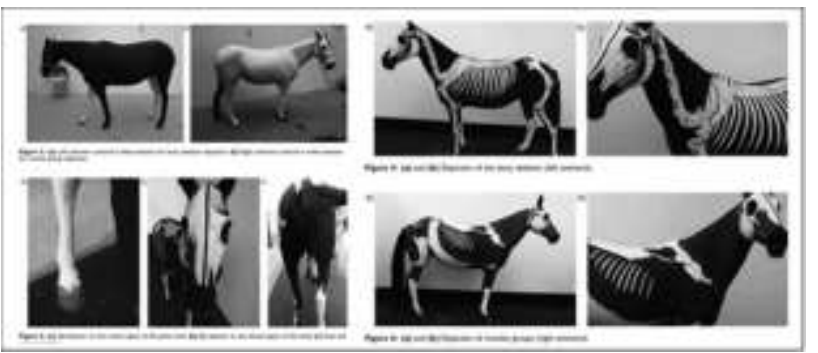

Figure 10 Body painting, using a painted garment to identify and palpate bone structures

Source: Sattin et al. (2018)

\subsection{Body projection}

Like the body painting technique, it is based on the ethical use of animals in teaching and its fundamental principle is the $3 \mathrm{R}$ 's (replacement), preventing the suffering caused by the use and handling of animals in teaching practices. and relies on virtual simulators, veterinary anatomy software and inanimate artificial models (Fig. 11) for its execution in the classroom, this cutting-edge technology was implemented in Mexico, in the Veterinary Medicine and Zootechnics degree of the University of the Valley of Mexico, Campus Coyoacán (Press UVM, 2015).

The advantages of this system is that it allows interaction with a variety of topics within anatomy and has applicability in different subjects that are fundamentally based on anatomy, such as surgical technique, systemic pathology, general pathology, zootechnics and the different clinics by species (Payró, 2018). The disadvantages of this technique are the costs of the software and the models, although against this, digital presentations and models made in an artistic or handmade way with a similar practicality can be used.

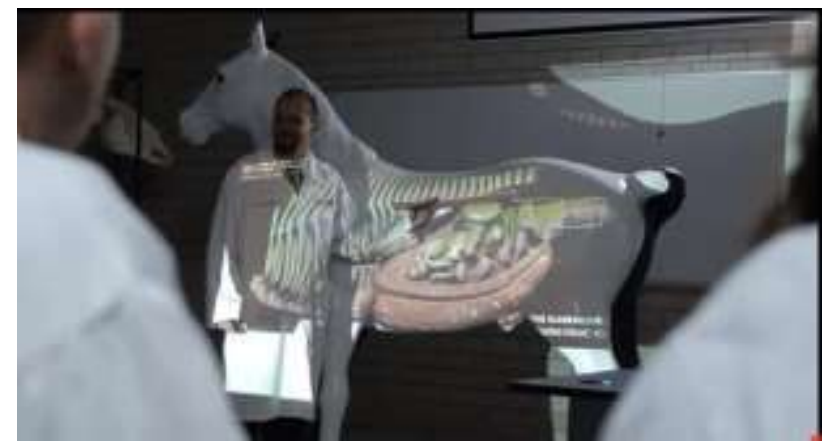

Figure 11 Body projection, animal body class II

Source: University of the Valley of Mexico. Bachelor of Veterinary Medicine and Animal Husbandry. Available in:

http://www.youtube.com/watch? $v=T f Z O a a l F Z W w \& t=1 s$

\subsection{Anatomical simulators}

Physical or mechanical models can be defined as those devices (mechanical, electrical, pneumatic, etc., or a combination of them) that allow simulating all or part of a biological system (Molina et al., 2012). Neri (2017) defines simulation as a technique that replaces and amplifies real experiences, evoking and replicating substantial aspects of the real world in an interactive way.

Within the clinical area of health sciences, innovative simulation models have been incorporated, these being a fundamental method for teaching, learning and as an integration system between basic and clinical sciences (Pérez \& Romero, 2014).

A simulator is considered to be any logical, physical or biological system capable of fully or partially simulating a process that we intend to study, which can be classified as mathematical (computer simulators, preexisting data), physical or mechanical (devices that allow simulating in whole or in part of some biological system) and biological (incorporation of ethical biological materials) (Molina et al., 2012). The bioethical basis for the use of simulators is based on the fact that they must be used for educational purposes before putting the safety of the subject / animal at risk (Baracaldo et al., 2019; Sandoval, 2018; Neri, 2017; Boroni \& Goldsack, 2016).

There are different types of simulators and they are located in a range that goes from videos and computer programs, through models of body parts, animal models, robotic surgical simulators, virtual reality simulators, augmented reality simulators, total procedure simulators, to full-scale models, also according to their level of complexity of operation and technology can be classified as:

- $\quad$ Low complexity: simulates the process without simulating your environment (training boxes, basic CPR manikins, bovine artificial insemination (AI) simulator).

- Medium complexity: they simulate the process including part of its environment and variations can be made in the procedure (bovine gynecological examination simulator for the diagnosis of the estrous cycle) (Pérez \& Romero, 2014).

ALCÁZAR-CHÁVEZ, Itzcoatl, OLMEDO-PÉREZ, Gerardo, ESTRADA-DÁVILA, María Graciela and TABAREZ-ROJAS, Abigail. Use of anatomical models in the teaching of veterinary anatomy as an animal welfare strategy. Journal of Technical Education. 2021 
- $\quad$ High complexity or advanced simulator: it simulates the process, its environment and has devices and sensors connected to a computer that allow feedback in real time (Martnsen \& Jukes, 2005).

\subsubsection{Virtual reality simulators}

Martinsen \& Jukes (2005) refer that generally when the term virtual reality is used, mention is made of advanced interactive software, with powerful 3D graphics (Fig. 12), which allows the user to immerse themselves in the experience when using it, since that facilitates psychomotor skills and procedures to be practiced in a highly sensory manner. In this exciting and growing field of technological development, the use of new technologies dramatically increases the opportunities for interaction in real time with a dynamic reality simulator, through the computer-human interface, a significant example is the Canine Virtual Anatomy program of the Collegue of Veterinary Medicine and Biomedical Sciences of Colorado Estate University (Fig. 12), which allows a dissection of the body of a real dog that was previously performed to later be registered in the software, and thus be able to visualize all the structures, in addition to containing hearing aids as well as interactive questionnaires.

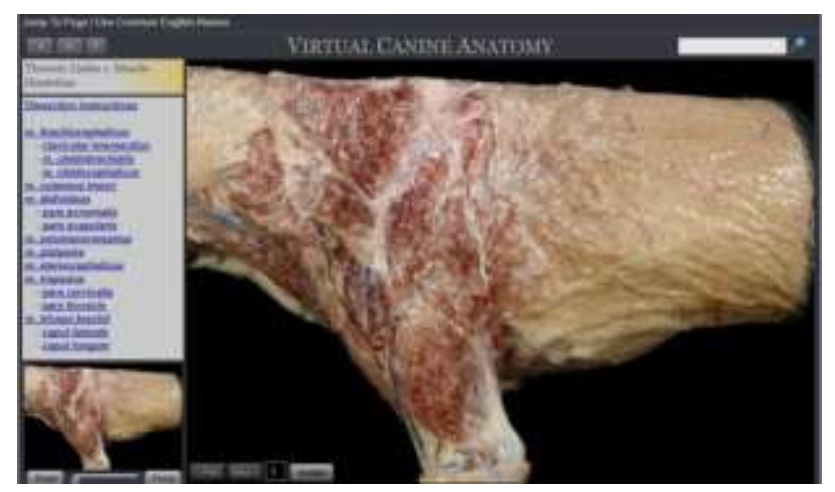

Figure 12 Virtual dissection of a dog carcass Source: Canine Virtual Anatomy dei College of Veterinary Medicine and Biomedical Sciences of Colorado Estate University. http://www.cvmbs.colostate.edu/vetneuro/

\subsubsection{Mechatronic or computerized simulators}

These models are composed of a physical model that contains a robotic or computerized system which works through software, therefore the participants can have an experience as close to reality making use of their capacities and technical skills in management or intervention. with the model, which with practice and successive repetition generate optimal capacities to be able to perform replications in animals in vivo or even interventions, but with a very low margin of error in terms of technical training (Fig. 13). Animals are not subjected to inappropriate handling and therefore they are not caused unnecessary suffering (Pérez \& Romero, 2014; Molina et al., 2012).

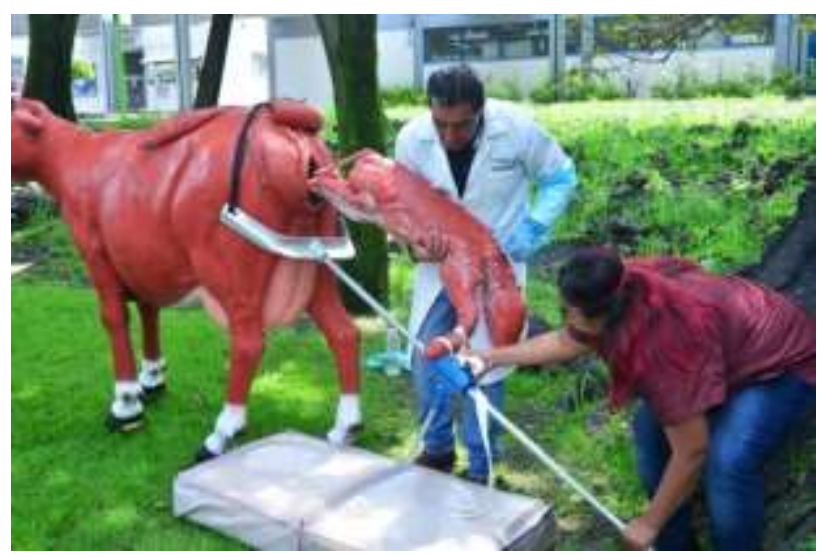

Figure 13 Obstetric maneuvers using a bovine female model

Source: Saavedra, (2018)

\section{Discussion}

It is necessary to analyze and reflect on the use of anatomical models as a bioethical and animal welfare strategy, given the use and experimentation with live animals or parts of these in teaching throughout the Veterinary Medicine career. It is necessary to take into consideration the following aspects: ethical justification and animal welfare, the comparative advantages and disadvantages between anatomical models and the use of cadavers, as well as vivisection, future challenges of the advancement in science and technology, as well as, the imminent changes in the teaching of veterinary medicine forced by a more conscious and bioethically responsible society. 
Therefore, each of the following aspects is addressed separately in order to finally reach an objective and transcendent reflection regarding the use and implementation of anatomical models in the teaching of veterinary anatomy as an animal welfare strategy.

Fisher (2016) mentions that the ethics of the use of animals and their welfare is a necessary topic to be discussed by different professional areas, as well as throughout the levels of education. Taking into account the new demands for ethical foundations that guide decision-making in the face of an ethical dilemma associated with a new reality in a globalized world, whose economic interests and the valuation of individual perceptions, a new intervention is necessary. Bioethics arises in this new scenario as a discipline that serves as a bridge between biological and human sciences, aiming at the dialogue of all subjects / actors involved in the search for new ethical paradigms that establish a more just relationship with all living beings and the environment.

Animal use resulting in injury or death has historically played an integral role in veterinary education, in disciplines such as surgery, physiology, biochemistry, anatomy, pharmacology, and parasitology. However, several safer alternatives now exist, including computer simulations, high-quality videos, "ethically sourced cadavers," such as medically euthanized animals, preserved specimens, surgical models and simulators, non-invasive self-experimentation, and supervised clinical experiences. (Ortiz, 2015).

The International Organization for Animal Health (OIE) recognizes the essential role of the use of live animals in research and education, the guidance that this entity promotes for animal welfare stipulates that the use of animals must be an important contribution to welfare. human and animal and stresses the importance of being based on the principle of the three Rs mentioned below:

1R: Replacement, that is, the use of methods that use cells, tissues or organs of animals (relative replacement), in addition to those that do not require the use of animals to achieve scientific objectives (absolute replacement).
2R: Reduction, that is, methods that allow researchers to obtain comparable levels of information from a number of animals or obtain more information from the same number of animals.

3R: Refinement, that is, methods to prevent, alleviate or minimize any known and eventual pain, distress, discomfort or lasting damage and / or improve the welfare of the animals. Refinement implies the appropriate selection of species with a lower degree of structural and functional complexity in their nervous system and a lower apparent capacity for experiences derived from their complexity. Possibilities for refinement should be considered and implemented throughout the life of the animal and include, for example, housing, transport and euthanasia (OIE, 2019).

According to Rivero (2018), Fisher (2016) and Carenzi \& Verga (2009), currently animals are attributed moral status, based on parameters such as sentience, the ability to experience pleasure and suffering and, for this reason, are considers it immoral to provide suffering to any sentient being and as mentioned (Ortiz, 2018), if any learning process involves morally objectionable behaviors, then surely we will tend to say that it is not justifiable, even if it is pedagogically effective, and therefore it is unjustifiable when in agreement With several authors, there are more viable alternatives under bioethical grounds that reduce or do not involve animal suffering (Balls, 1994; Martinsen and Jukes, 2005; Knight, 2008; Carenzí \& Verga, 2009; Cardona, 2010; DeHoff et al., 2011 ; Muñetón \& Ortiz, 2011; Villareal \& Medina 2011; Ozkadif \& Eken, 2012; Téllez, 2012, Pérez \& Romero, 2014, Sanin et al., 2014, Re. Et al., 2014, Rodríguez \& Suárez, 2014. Sanchis , 2015, Breasts et al., 2015, Cruz, 2016, Fischer, 2016, Boroni \& Goldsack, 2016, Soler et al., 2016, Neri-vela, 2017, Vélez \& Robinson, 2017, Balasteguí et al., 2018, Hernández et al., 2018, Sattin et al., 2018, Terrado et al., 2018, Tabares, 2018, Baracaldo et al., 2019, Hackman et al., 2019, Leandro et al., 2019, Juárez, 2019, Payró, 2019, Tamayo et al., 2019, Villareal \& Mendoza, 2011, Cavalcante et al., 2020). 
It is also important to mention the disadvantages, advantages and disadvantages of the use of anatomical models in practical teaching. As can be seen, the main problem with anatomical models of 2D structures (manuals or textbooks) is the clear lack of understanding with which students can develop a thought and spatial distribution of said structure as a whole and not as several images united to form one, from different points of view (Sanchis, 2015).

According to Nieto et al. (2014) it is necessary to use preserved biological material, since, although in didactic resources such as drawings, diagrams, slides (2D Models) the shape of the structures can be appreciated, it is not possible to perceive other important characteristics such as size, external appearance, color, texture, consistency, distribution, and topographic relationships.

While Muñetón \& Ortiz (2011) report that one of the drawbacks of using preserved biological material is the smell produced by the formaldehyde vapors with which the different anatomical pieces have been made, this product has the advantage of fixing the fabrics, avoid their decomposition and have an acceptable price in the market. The problem comes with the side effects attributed to it, such as eye, nose and throat irritation, breathing difficulties, bronchitis, sensitization, allergy, and its classification as a probable human carcinogen.

On the other hand, physical models also have some drawbacks, some anatomical structures, whether replicas or real, are difficult to get and store correctly or have a very high price for most schools. The physical structures that are easier to achieve are usually present in limited numbers, slowing down the study of all the students in a classroom (Sanchis, 2015).

While the convenient use of plastic materials throughout the history of anatomy has been a valuable support for teaching, either as a method of inclusion of pieces, especially when they must remain in a liquid medium, as well as in the injection of self-curing acrylic resins, which have made it possible to make molds of blood vessels followed by corrosion (Villarroel \& Medina, 2011).
According to Knight (2008) and Molina (2012), the use of models and simulators increases teaching efficiency and decreases costs, together with a greater potential for adaptation and repeatability of the learning exercise, which are usually the result of use of humane teaching methods. Increased student confidence and satisfaction, better preparation for labs, and decreased student stress can also occur. Improved information retrieval and communication skills of students, as well as improved student attitudes towards computers and increased employers' perception of computer literacy can also result from these methods.

The use of simulators in veterinary medicine is based on the objective of preserving animal welfare and reducing the risks of injury, both for students and patients, allowing quality teaching to be provided, improving skills in the clinical management of animals. animals (Pérez $\&$ Romero, 2014). The use of simulators in university teaching allows practical training in situations similar to real ones, so that students are trained in the technique, by repeating a maneuver multiple times that allows them to ensure its correct performance before applying it to real individuals. (Baracaldo, 2019). That is to say, it is not a matter of not carrying out practices with real individuals, but rather reducing errors in practical intervention as much as possible and consequently avoiding unnecessary suffering as a basic principle of animal welfare (Payró, 2018).

At present, the teaching of medicine and veterinary medicine around the world has shown great advances in materials, instruments, techniques, ethics and laws, which have radically changed, characterized by a vertiginous advance in science, which has led to an amazing change in different areas, allowing to know infinity of processes that explain the reason for many diseases, this in turn generates a simpler way of understanding and executing medical acts, in addition to facilitating the students of this discipline, the learning and practice in a safer way, fundamental characteristics in this area, where the health and well-being of patients is at stake (Baracaldo et al., 2019). 
According to Sanín et al. (2014) currently the teaching of medical sciences is changing and it is increasingly common to observe a significant increase in the use of models for teaching and learning in the training processes of doctors, dentists, nurses, physiotherapists, paramedics, among others , but in agricultural sciences the implementation is more recent and only since 1990 some models or simulators began to be used in teaching and whose didactics is still under discussion.

Basic education subjects such as anatomy represent for students not only a high rate of academic repetition, but also one of the most important reasons for student dropouts from professional careers. Therefore, it is a duty of teachers to promote the study and appropriation of knowledge in order to guarantee a successful and ethical professional training, with the growing development of information technologies in the academic environment, anatomical models are a resource that perfectly adjusts to the needs of these dynamics (Sanín, et al., 2014).

The modern university must prepare its students to carry out their profession adequately, it is therefore essential that the educational process be analyzed with a double perspective: how students learn and consequently what and how to teach them.

Historically, live animals have been used to teach procedures in veterinary medicine. However, in the last decade, new technologies such as manuals, videos, images and augmented reality simulators have been produced, seeking to develop skills and abilities in students (Cardona, 2010). According to Gutiérrez (2007), a clear reflection of the good use of ideal techniques for student learning is that students find these innovations attractive, easy to understand, giving them a self-need to learn, encouraging them to search for knowledge and complex skills; through the acquisition, encoding, retrieval and processing of information; achieving significant, analytical, practical knowledge and with the necessary skills for its application in practice (Mendoza et al., 2012).
Society, the environment, the development of technology, the development of agriculture, the emergence of disease, the human-animal bond, and culture are all changing rapidly. To remain relevant, veterinary medicine must adapt and respond to changing needs in society. The dynamics of social change cannot be interrupted, but the success of the profession will be determined by how it meets the requirements of society. To understand these changing needs, veterinary medical colleges must broaden the scope of education they offer; however, colleges are not expected to provide education to veterinary medicine students in all areas of professional focus deemed necessary to meet the needs of society (Willis et al., 2007). According to Téllez (2012), ethical (or unethical) behavior is learned during the career and this is reflected in professional practice. As they are trained, a framework of norms, values or beliefs that shape attitudes in students is transmitted without express intention that will influence their work.

As mentioned by Willis et al. (2007) it is essential to develop pedagogical strategies based on anticipating unexpected changes. This allows preparation for various future challenges in a timely manner, it does not predict or forecast the future nor is it a strategic plan. In other words, it anticipates and creates multiple and plausible futures that are possible and credible. These can be positive or negative, but with their diversity they show issues and perspectives that would not have been considered initially.

A case that exemplifies the above is the situation currently being experienced at a global educational level caused by the pandemic caused by the SARS CoV-2 virus (Covid 19) which forced a drastic change from face-to-face education to virtual education, forcing teachers and students to use information technologies (ICTs) as a means for the development of their teaching-learning process as a professional. Likewise, within this period, the lack of artificial anatomical models available within the universities was evidenced, which, added to the technical difficulties in terms of knowledge and management of ICTs by students and teachers, made the teaching-learning process learning would be impaired in terms of practical application in the different subjects. 


\section{Conclusion}

Derived from the growing scientific, technological and bioethical development, it seems essential that the professionals of Veterinary Medicine and Zootechnics of the XXI century, know and actively participate in the design, innovation and technology of the industry of anatomical models with application not only in the sciences veterinary, but in general in the health sciences and the interdisciplinarity that these entail. All this from the fact that, at present, the practices related to the use of animals in research, teaching and even in the production and care given to them in general, are being questioned from various aspects such as: the rights of the animals, animal welfare, sustainability, operating costs, feasibility, management and reproducibility of exercises, where different professions are involved.

In addition, there is evidence of the need to develop academic programs based on problem solving, meaningful learning, learning by competencies and the interdiscipline of veterinary medicine professionals, which creates the opportunity and need to rethink pedagogical strategies with the purpose of including in the degree of Veterinary Medicine and Zootechnics, of the university institutions where it is taught, the use of artificial anatomical models and other technologies that last in time and space so that they are strategic tools and thus avoid unnecessary animal suffering, facilitating the practices in the field with better quality and guaranteeing the technical, surgical or clinical skills of the students in training and carrying out the ethical handling of the animals.

\section{References}

Balastegui-Martínez, MT., ChicharroAlcántara, D., García-Manzanares, MD, Gómez-Roda, O. \& Terrado Vicente, J. (2018). Utilización de modelos anatómicos realizados con plastilina como herramienta para el aprendizaje de la anatomía veterinaria. I Jornadas Nacionales de innovación Docente en Veterinaria (INNOVET). Revista complutense de ciencias veterinarias. 8(1). Disponible en: https://www.uchceu.es/docs/conocenos/ceuinnova/memoria-proyectos-innovacion2018.pdf
Balls, M. (1994). Replacement of animal procedures: alternatives in research, education and testing. Laboratory animals. 28 (3), 193$211 . \quad$ Disponible https://pubmed.ncbi.nlm.nih.gov/7967458/

Baracaldo, A., Domínguez, P., Franco, N., Atuesta, J. \& Robayo, D. (2019). Uso de un simulador bovino para prácticas de palpación transrectal. Revista Investigación Veterinaria, Perú. 30 (3), 1342-1346. [fecha de consulta 10 de septiembre de 2020]. Disponible en: http://www.scielo.org.pe/pdf/rivep/v30n3/a40v 30n3.pdf

Barros-Bastida, C. \& Barros-Morales, R. (2015). Los medios audiovisuales y su influencia en la educación desde alternativas de análisis. Revista Universidad y Sociedad. 7(3), 26-31. Recuperado de: http://scielo.sld.cu/scielo.php?script=sci_arttext \&pid=S2218-36202015000300005

Boroni, C. \& Goldsack, A. (2016). Uso de modelos de simulación en la enseñanzaaprendizaje de habilidades clínicas en pequeños animales. En: Mejores estrategias, prácticas y actividades docentes para una enseñanza efectiva del bienestar animal en América latina [ e-Book] World Animal Protection SáO Paulo: Word animal Protection. 61- 69.

Canine Virtual Anatomy del Collegue of Veterinary Medicine and Biomedical Sciences of Colorado Estate University. Disponible en: http://www.cvmbs.colostate.edu/vetneuro/

Cardona, E. \& Salas, S. (2016). Estrategias y practicas docentes que fomentan el uso humanitario de animales en educación e investigación. En Mejores estrategias, prácticas y actividades docentes para una enseñanza efectiva del bienestar animal en América latina [ e-Book] World Animal Protection. SáO Paulo: Word animal Protection. 55-59.

Carenzi, C. \& Verga, M. (2009). Animal welfare: Review of the scientific concept and definition. Ital. J. Anim. Sci. 8 (suppl. 1), 2130 Disponible en: https://www.researchgate.net/publication/41393 397Animal_welfare_Review_of_the_scientific_ conce pt_and_definition 
Castillo, G., Félix, J., Gaínza-Leyva, JC., Alerm-González, A. \& Barrios-Rosquett, LS. (2005). Los costes de la investigación y la docencia cuando se utilizan animales de laboratorio. Revista Habanera de Ciencias Médicas. 4(5), 1-4. Disponible en: https://www.redalyc.org/articulo.oa?id=180420 144006

Cavalcante-das Neves, E., Charles-Pelizzari, R., OliveiraSiham KassabKleber dos Anjos, S. \& Karaccas de Carvalho, LY. (2020). 3D anatomical model for teaching canine lumbosacral epidural anesthesia. Acta Cir. Bras. 35 (6), 1-8. Disponible en: https://doi.org/10.1590/s0102-

865020200060000008

Chaix, L. \& Méniel, P. (2005). Manual de Arqueozoología. París: Ariel Prehistoria.

DeHoff, ME., Krista L. Clark \& Karthikeyan, Meganathan. (2011). Learning outcomes and student- perceived value of clay modeling and cat dissection in undergraduate human anatomy and physiology. Advances in Physiology Education. Adv Physiol Educ. 35, 68-75. Disponible en: https://doi.org/10.1152/advan.00094.2010.

Dyce, KM., Sack WO. \& Wensing, CJG. (2012) Anatomía veterinaria. $4^{\mathrm{a}}$ ed. Ed. Manual Moderno. México.

Fischer, M. (2016). Ética en el uso animal y bienestar animal. En: Mejores estrategias, prácticas y actividades docentes para una enseñanza efectiva del bienestar animal en América latina [ e-Book] World Animal Protection. SáO Paulo: Word animal Protection. 83-87

Flores, J., Ávila, J., Rojas, C., Sáenz, F., Acosta, R. \& Díaz, C. (2017). Estrategias didácticas para el aprendizaje significativo en contextos universitarios. Chile: Unidad de Investigación y Desarrollo docente.

Frías, L. (2019). Museo de anatomopatología veterinaria. Colección de animales con alteraciones. Gaceta UNAM.15. Suplemento especial
Hernández-Muñoz, Óscar., Sánchez-Ortiz, A. \& Matía-Martín, P. (2019). Anatomía animal. Técnicas digitales para la reconstrucción escultórica de la apariencia original de un modelo de cera del siglo XIX. Intervención. 10 (19), 64-76. http://www.scielo.org.mx/scielo.php?script=sci _abstract\&pid=S2007-

249X2019000100064\&lng=es\&nrm=isohttps:// doi.org/10.30763/intervencion.2019.19.209

Hackmann-Conrado, H., dos-Reis, L.D.A, \& de-Assis-Neto, AC. (2019). Digital Revolution In Veterinary Anatomy: Confection of Anatomical Models of Canine Stomach by Scanning and Three- Dimensional Printing (3D). International Journal of Morphology. 37(2), 486-490. Disponible en: https://dx.doi.org/10.4067/S071795022019000200486

Juárez-Portilla, CJ., Zepeda-Hernández, RC., Sánchez-Salcedo, JA., Flores-Muñoz, M., López-Franco, Ó. \& Cortés-Sol, A. (2019). El uso de los animales en la investigación y en la enseñanza: lineamientos y directrices para su manejo. Revista Eduscientia. Divulgación de la ciencia educativa. 2(4), 4-19. Disponible en: https://eduscientia.com/index.php/journal/articl e/view/52

Knight, A. (2008). Humane Teaching Methods Demonstrate Efficacy in Veterinary Education. Australian and New Zealand Council for the Care of Animals in Research and Teaching Ltd. Disponible en: https://anzccart.org.nz/app/uploads/2017/06/20 06proceedings.pdf\#page $=123$

Leandro, RM., Filho, RPPF., De Silvio MM., Quilici, AP., Sattin, MM., Paretsis BF. \& Souza VA. (2019). Construction of the equine digestive system: a tool for teaching topographical anatomy. J Vet Med Educ. 46(1), 108-115. doi: 10.3138/jvme.0317-043r.

Lenis-Sanín, Y., Carrillo, D. \& TamayoArango, L. (2013). Modelos didácticos como estrategia para la enseñanza y el aprendizaje de los sistemas orgánicos animales en la Facultad de Ciencias Agrarias de la Universidad de Antioquia. Uni-Pluriversidad, 12, 44-51. Disponible en: https://revistas.udea.edu.co/index.php/unip/artic le/view/15353 
López, R. (2019). Museo de anatomopatología veterinaria. El propósito de este espacio puma es apoyar la enseñanza. Gaceta UNAM. Disponible en: https://www.gaceta.unam.mx/museo-deanatomopatologia-en-medicina-veterinaria/

Martínez, R. \& Ramírez, S. (2015). Evaluación de la enseñanza aprendizaje y la medición educativa. En Alternativas para nuevas prácticas educativas, Libro 8 . Nuevos modelos educativos, es un libro generado como parte del II Congreso Internacional de Transformación Educativa. Ed. Amapsi, Tlaxcala, México. 83.

Martinsen, S., \& Jukes, N. (2005) Towards a humane veterinary education. J Vet Med Educ. 32(4), 454-460. doi: 10.3138/jvme.32.4.454

Molina-Martínez, JL., Silveira-Prado, EA., Heredia-Ruiz, D., Fernández-Caraballo, D., Bécquer- Mendoza, L., Gómez-Hernández, T., González-Madariaga, Y. \& Castro, M. (2012). Los simuladores y los modelos experimentales en el desarrollo de habilidades quirúrgicas en el proceso de enseñanza-aprendizaje de las Ciencias de la Salud. REDVET. Revista Electrónica de Veterinaria. 13(6), 1-23. Disponible en: https://www.redalyc.org/pdf/636/63624434013. pdf

Molina-Lopez, AM., Diz-Plaza, A., SoldadoAyala, N., Diz-Conde,L., N., Lora-Benítez, A., Galisteo- Martinez, A., Vivo-Rodríguez, J., A., Navas-Lloret, JM., Barazona-Carmona, MI.,Bujalance- Reyes, F., Rueda-Jiménez, A., Fernandez-Díez, A., Pérez-Barquero, EM. \& Salvago-Moyano, R. (2020). Elaboración de modelos anatómicos mediante técnicas de plastinación como alternativa al uso de animales en docencia y como recurso esencial en el proceso de enseñanza-aprendizaje. Revista de Innovación y Buenas Prácticas Docentes. 9(1), 80-90. Doi: https://doi.org/10.21071/ripadoc.v9i1.12612.

Muñetón, CA. \& Ortiz, A. (Julio-diciembre del 2011). Conservación y elaboración de piezas anatómicas con sustancias diferentes al formol en la Facultad de Ciencias Agropecuarias de la Universidad de LaSalle. Revista de Medicina Veterinaria. 22, 51-55.
Museo de anatomía de Murcia. Figure 2. Modelos anatómicos orgánicos esqueleto de bovino. Disponible en: https://www.um.es/web/museoveterinario/colecciones/esqueletos. Museo de anatomía de Murcia. Piezas anatómicas plastinadas. Disponible en: https://www.um.es/web/museoveterinario/colecciones/piezas-plastinadas

Neri-Vela, R. (2017). El origen del uso de simuladores en medicina. Rev Fac Med UNAM. 60(Suppl: 1), 21-27. Sitio web: https://www.medigraphic.com/pdfs/facmed/un2017/uns171c.pdf

Nieto, J., García, T., Pichardo, Ma., Reyes, A. \& Soto C. (2014). Técnicas para preservar piezas anatómicas. México D.F: Universidad Nacional Autónoma de México, Facultad de estudios Superiores Cuautitlán.

Organización Mundial de Sanidad Animal OIE. (2019). Código Sanitario para los Animales Terrestres. Disponible en: https://www.oie.int/fileadmin/Home/esp/Health _standards/tahc/current/es_chapitre_aw_researc h_educ ation.htm

Ortiz, G. (enero-marzo 2016). Víctimas de la educación. la ética y el uso de animales en la educación superior. Revista de educación superior, 45-1(177), 147-170.

Özkadif, Sema \& Eken, Emrullah. (2012). Modernization process in veterinary anatomy education. Energy Education Science and Technology Part B: Social and Educational Studies. 4 (2), 957-962.

Payró, J. (diciembre 2015- enero 2016). Innovación en la utilización de simuladores para la formación y enseñanza de técnicas básicas en endoscopia digestiva Veterinaria en la Universidad del Valle De México (UVM). Actualidades en Medicina Veterinaria y Zootecnia México, año 5, Número 14, 12-34.

Pérez, E. \& Romero, T. (2014). Uso de simuladores Mecatrónicos en la enseñanza de la medicina veterinaria. Disponible en: https://eventos.cch.unam.mx/simposiorobotica/ memorias/2014/trabajos/p00901 uso_de_simuladores_ mecatronicos_en_la_ensenanza_ve.pdf 
Prensa UVM (2015). Contribuye UVM al bienestar animal al eliminar en su programa académico el sufrimiento innecesario de especies en su programa académico. Disponible en: https://laureatecomunicacion.com/prensa/contribuye-uvm-albienestar-animal-al-eliminar-el-sufrimientoinnecesario- de-especies-en-su-programaacademico/\#.YSKJzOug_IU

Rivero-Weber P. (2018). Zooética. Una mirada filosófica a los animales. Ed. Fondo de Cultura Económica, Universidad Nacional Autónoma de México. México

Saavedra, D. (2018) Aplicación de simuladores mecatrónicos. Potencia la universidad la formación de veterinarios. Recrean el nacimiento de un becerro, ordeña y exploración de la glándula mamaria, toma de muestras sanguíneas, técnicas de sutura, aplicación de fármacos e inseminación artificial y cirugías. Gaceta UNAM. Disponible en: https://www.gaceta.unam.mx/potencia-launiversidad-la-formacion-de-veterinarios/

Sánchez, C., Andromaco, M., Páez, R., Barello, M. \& Gastón, P. (2012). Estudio de nuevas técnicas para conservación de piezas anatómicas, plastinación. Revista de Salud pública. 16(3), 27-32. Disponible en: http://www.saludpublica.fcm.unc.edu.ar/sites/d efault/files/RSP12_3_06_art\%203.pdf

Sanchis, L. (2015). Eficacia comparada entre modelos $3 \mathrm{~d}$ y modelos físicos en el aprendizaje de estructuras anatómicas en zoología. Memoria de trabajo de fin de grado, Universitat de les IIIes Balearsd.

Sattin, M., Silva, VKA., Leandro, RM., FozFilho, R. \& De Silvio MM. (2018). Use of a garment as an alternative to body painting in equine musculoeskeletal anatomy teaching. J. Vet Med Educ. 45(1), 119-125. Doi: 10.3138/jvme.0716-122r1

Soler, Y., Ramírez, W., Yaguana, J., Antúnez, G. \& Flores, A. (2016). Modelos alternativos al servicio de la enseñanza y la bioética en Medicina Veterinaria. Revista Electrónica de Veterinaria. 17(12), 1-10. Disponible en: https://www.redalyc.org/articulo.oa?id=636490 52006
Senos, R., Ribeiro, M., Martins, K., Pereira, L., Mattos, M. \& Júnior, J., Rodrigues, M. (2015). Acceptance of the bodypainting as supportive method to learn the surface locomotor apparatus anatomy of the horse. Folia Morphol. 74(4), 503-507. Doi:10.5603/FM.2015.0023.

Szunyoghy, A. \& Fehér, G. (2010). Escuela de dibujo de anatomía animal. Barcelona, España: Tandem Verlag Gmbh.

Tamayo, L., Arango, \& Osorio J. (2020). Modelos: otra forma de aprender anatomía. Experimenta revista de divulgación científica de la Universidad de Antioquía. Grupo de investigación CIBAV y Semillero Anatomía Animal, Universidad de Antioquía. 53-55. Disponible en: https://revistas.udea.edu.co/index.php/experime nta/article/view/342486/20802854

Tabares, N. (2018). Nuevas tecnologías aplicadas en veterinaria. Argos. (196), 98-99. Disponible en: https://issuu.com/editorialservet/docs/argos_19 6_mr/104

Téllez-Ballesteros, E. (2017). El uso de los animales en la educación. Un análisis bioético. Murmullos Filosóficos, 2(3), 52-59. Disponible en:

http://www.revistas.unam.mx/index.php/murmu llos/article/view/59196

Terrado-Vicente, J., Gómez-Roda, O., Balastegui-Martinez, MT., ChicharroAlcántara, D., \& Garcia- Manzanares, MD. (2018). "Connecting students" de anatomía veterinaria. VII Jornada de innovación y mejora de la docencia. 253-258. Disponible en: https://www.uchceu.es/docs/conocenos/ceuinnova/memoria-proyectos-innovacion2018.pdf

Trujillo-Mascia, N. (2016). Los museos veterinarios: puntos de encuentro entre la historia y la ciencia. Intervención, Revista Internacional de Conservación, Restauración y Museología, 7(14), 42-47. Disponible en: https://www.redalyc.org/articulo.oa?id=355646 711005

Universidad del Valle de México. Licenciatura en Medicina Veterinaria y Zootecnia (2014): Disponible en: http://www.youtube.com/watch?v=TfZOaa1FZ $\mathrm{Ww} \& \mathrm{t}=1 \mathrm{~s}$

ALCÁZAR-CHÁVEZ, Itzcoatl, OLMEDO-PÉREZ, Gerardo, ESTRADA-DÁVILA, María Graciela and TABAREZ-ROJAS, Abigail. Use of anatomical models in the teaching of veterinary anatomy as an animal welfare strategy. Journal of Technical Education. 2021 
Vélez-García, JF., \& Ruiz-Lozano, R. (2017). Reflexión sobre los procesos de enseñanzaaprendizaje de la anatomía veterinaria. International Journal of Morphology. 35(3), 888-892. https://dx.doi.org/10.4067/S071795022017000300015

Veterinary anatomy. Muscles of the neck and shoulder girdle part 1. Disponible en: https://www.youtube.com/watch?v=Fkv6jk1894 $\mathrm{M} \& \mathrm{t}=256 \mathrm{~s}$

Villaescusa, FA., Re, M., Calleja, L., DeGaspar, I., Blanco, FJ., González, JV., Parrilla, G., Mazzucchelli, F. \& García- Sancho M. (2014). Desarrollo de material audiovisual para la enseñanza de la exploración física de la vaca. I Jornadas Nacionales de innovación Docente en Veterinaria. Revista complutense de ciencias veterinarias. 8(1). Disponible en: 30-2014-0115-24.pdf (ucm.es)

Villarroel-Guerra, M. \& Medina-Otazo, E. (2011). Técnica anatómica para restaurar y/o reproducir piezas óseas humanas de difícil obtención, para la investigación y docencia científica. International Journal of Morphology. 29(2), 532-536. Disponible en:

https://www.scielo.cl/scielo.php?script=sci_artt ext\&pid=S0717-95022011000200038

Waters, JR., Van Meter P., Perrotti, W., Drogo, S. \& Cyr, RJ. (2011). Human clay models versus cat dissection: how the similarity between the classroom and the exam affects student performance. Adv Physiol Educ. 35(2), 227-36. doi: 10.1152/advan.00030.2009.

Willis, N., Monrroe, F., Potworowoki, A., Halbert, G., Evans, B., Smith, E. \& Andrews, K. (2007). Visión del futuro de la educación médica veterinaria: El proyecto de previsión de la asociación americana de colegios de médicos veterinarios. Organización Panamericana de la Salud. 7-27 Disponible en: capa_revista_EMV (unam.mx) 